\title{
The Stable Isotope Composition of the Calcite Cement in the Fluvio-Deltaic Reservoir Sandstones of the Lower Acacus Formation, Ghadames (Hamada) Basin, NW Libya
}

\author{
Omar B. Elfigih \\ Associate Professor, Petroleum Geologist, Department of Earth Sciences, Faculty of Science, \\ University of Benghazi, Benghazi-Libya
}

\begin{abstract}
The Lower Acacus Formation of Upper Silurian age in the Ghadames (Hamada) Basin, NW Libya, is an important sandstone reservoir. The formation is buried at a depth of 7500ft in the southern part of the basin and down to 8500ft in the northern part.
\end{abstract}

The Lower Acacus Formation is characterized by regressive and transgressive cyclic sequences of sandstones, siltstone and shale, whose deposition and distribution were controlled by relative changes in the sea level. The Lower Acacus Formation deposited in a fluvio-deltaic system that prograded northward and into the northwestern flank of the intracratonic Ghadames (Hamada) Basin.

A combination of optical microscopy and stable isotopic analyses were used in order to provide detailed constraints on the composition of calcite cements, the evolution of pore fluid types, and the relative timing of calcite cement precipitation.

The principal cements occluding porosity include carbonates, quartz overgrowth, and some subordinated kaolinite and illite. Two types of calcite cements have been distinguished based on texture and manner of occurrence in thin-sections: 1) Patchy calcite cement which regarded as shallow calcite cement, occurs in the southerly shallower portions of the basin characterized the fluvial, iron oxide-rich sandstones (Af2-Af7 units). 2) Poikilotopic calcite cement which regarded as deep calcite cement, occurs in the northerly deeper parts of the basin characterized the deltaic sandstones (A8-A14 units).

Isotopic compositions of calcite cements in the Lower Acacus Formation reflect different regional paleo-fluid regimes from meteoric to mixed waters. Relatively shallow depth patchy calcite-cement is associated with sandstone units of fluvial origin. This cement formed from enriched $\delta^{18} \mathrm{O}$ meteoric waters at low temperature and the lighter negative $\delta^{13} \mathrm{C}$ nature of this calcite suggests an involvement of organically derived $\mathrm{CO}_{2}$. Deeper depth poikilotopic calcite-cement formed from waters depleted in $\delta^{18} \mathrm{O}$ that became progressively hotter, more reducing and saline as they flowed down-dip to mix with the saline waters in sandstone-siltstone units of deltaic origin, with negative $\delta^{13} C$ values which probably record the increasing importance with depth of bicarbonate production by thermal decarboxylation.

It is important to note that it is difficult to determine the timing (early or late) of the patchy shallow to homogeneously distributed poikilotopic deep calcite cements. However the data suggest that two possible deltaic systems prograded from NE to W and from $S$ to NNW may be inferred, in which both the shallow and the deep calcite cements were formed synchronously. The shallow cement was precipitated in the fluvial sandstones from meteoric waters and the deep calcite cement was precipitated in the deltaic sandstones as the waters flowed down-basin becoming progressively more saline and reducing.

Keywords: Stable isotope, Calcite cement, Lower Acacus Sandstones, Ghadames Basin.

\section{INTRODUCTION}

The most important oil reservoirs in western Libya are found in the Ghadames (Hamada) Basin (Fig. 1). The sandstones of the Lower Acacus Formation of Upper Silurian age contain the largest hydrocarbon reserves. Analyses related to the diagenesis effect on these reservoir sandstones are scattered. Sedimentological, and petrological study including diagenetic processes of these sandstones and their carbonate cements as well as a general diagenetic sequence of the principal events have been completed by [1]. 
The spatial distribution of diagenetic alterations in fluvial, deltaic (transitional) and marine sediments is strongly influenced by depositional facies, sea-level changes and the extent of mixing between diagenetic fluids of marine and meteoric waters [1]. Likewise, the burial depths at which the diagenetic reactions between sediments and fluids occurred may vary considerably depending on the burial-thermal history of the sequence.

The purpose of this paper is to define and investigate the possible calcite cement types in the Lower Acacus sandstones and discuss their possible relation to the depositional environment or with the fluids that circulate at burial depth.

A combination of optical microscopy and stable isotopic analyses were used in order to provide detailed constraints on the evolution of pore fluid composition, and the relative timing of calcite cement precipitation.

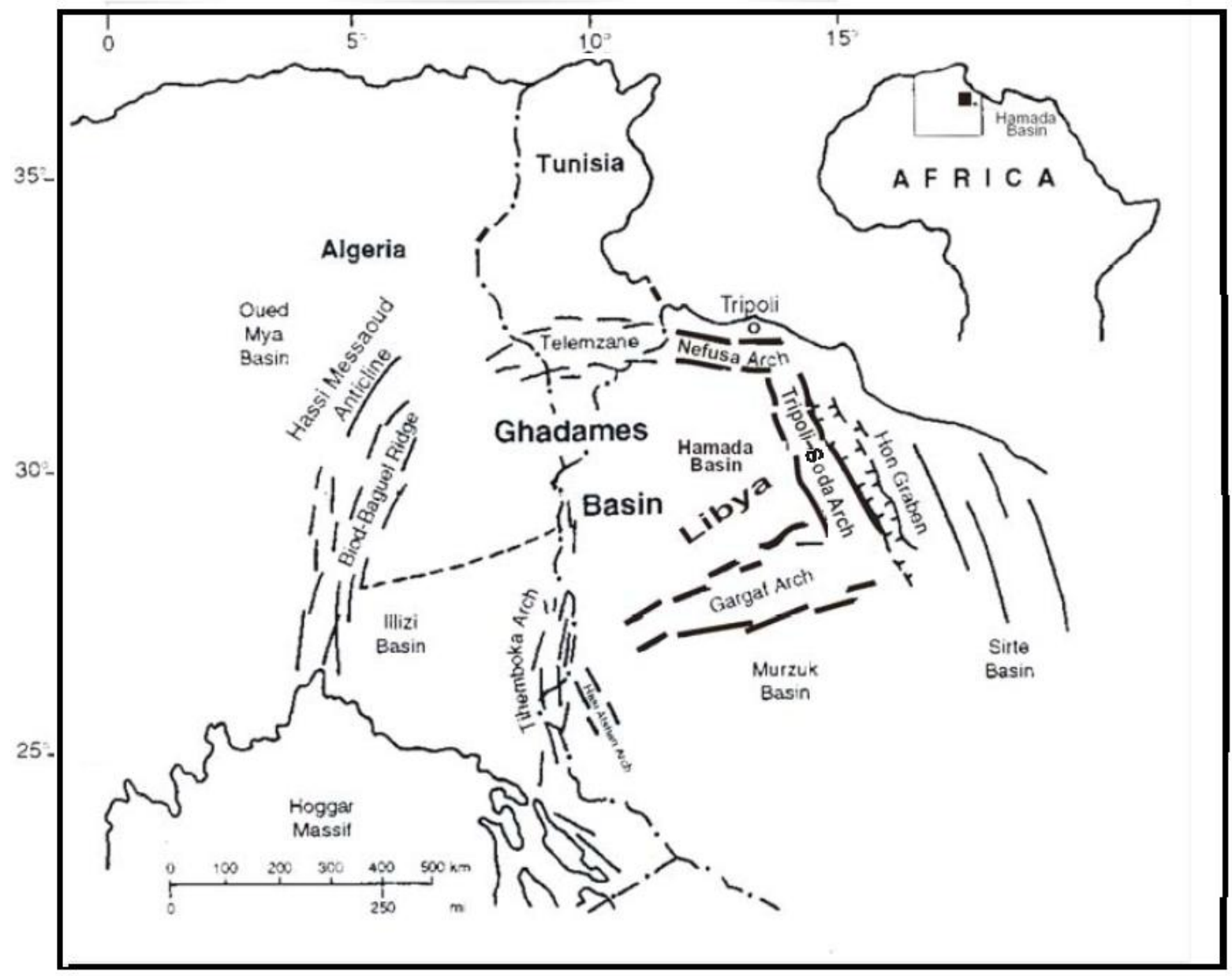

Figure 1. Regional map showing location of the Ghadames (Hamada) Basin and it important tectonic elements, NW Libya (modified after [2]).

\section{GeOlogical SETTING}

Structurally, the Hamra Basin of Libya forms part of a larger intra-cratonic Ghadames depression which stretching across eastern Algeria, southern Tunisia and NW Libya (Fig.1). The Ghadames Basin is bounded by the Nefusa Arch to the north, the Tihemboka- Gargaf Arches in the south and the Tripoli-Soda Arch to the east. Seismic and geologic interpretation of subsurface data from drilled wells show the structural history of the Hamada Basin, where some faults and folds were inverted followed by erosion produced unconformities through time (Fig. 2). The basin internal architecture is dominated by a Hercynian unconformity, which separates a truncated Cambro-Ordovician to Carboniferous succession below from a northward-thickening Mesozoic-early Tertiary wedge above (Fig. 2). In general, the recent structures were influenced by previous tectonic events that took place during Precambrian and Lower Paleozoic. 


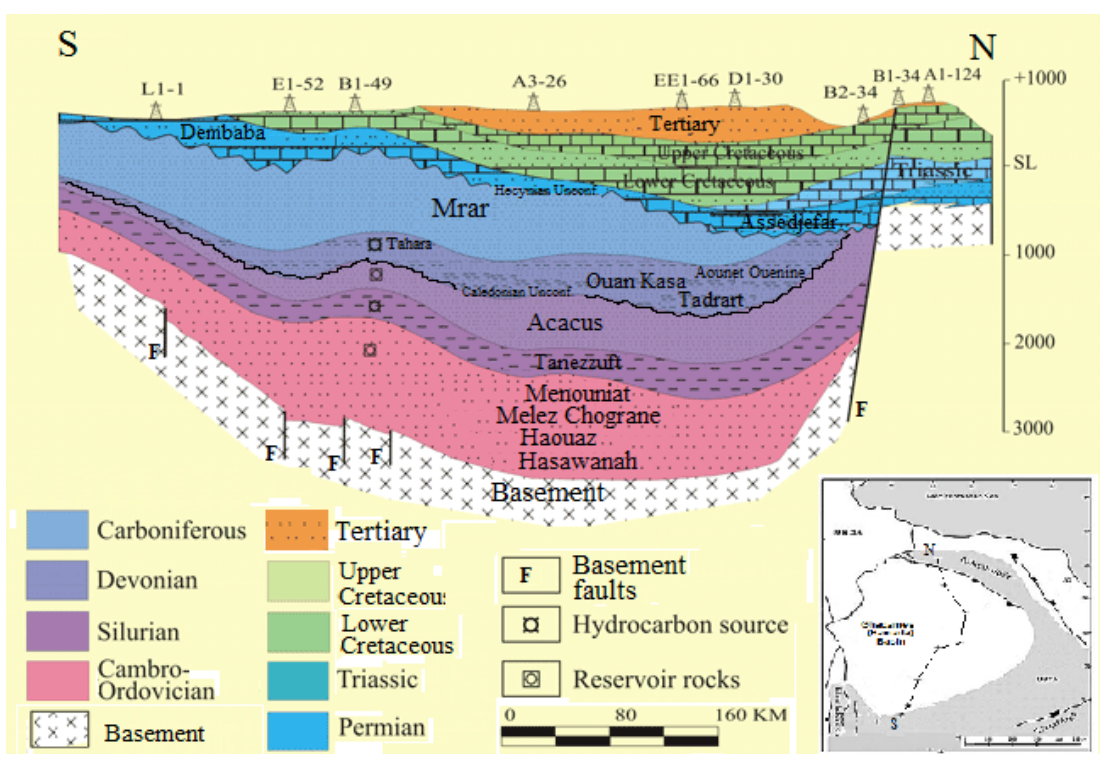

Figure 2. $N$-S Regional Structural cross section showing present day structures in the intracratonic Ghadames (Hamada) Basin, NW Libya (modified after [3]).

Stratigraphically, the Upper Silurian Lower Acacus Formation was deposited over a stable intracratonic platform in a passive margin with low subsidence. It is overlain by the Middle Acacus shale with gradual transgressive contact and underlain by the Tanezzuft shale with sharp transgressive contact (Fig. 3). The Lower Acacus Formation is characterized by regressive and transgressive cyclic sequences of sandstones, siltstone and shale (Fig. 3), whose deposition and distribution were controlled by relative changes in the sea level [4]. The Lower Acacus Formation deposited in a fluviodeltaic system that prograded northward and into the northwestern flank of the intracratonic Ghadames (Hamada) Basin [4]. Based on well log correlation, the Lower Acacus Formation is subdivided stratigraphically into 14 coarsening-upward deltaic units (A1-A14) which are laterally equivalent to 7 fining upward fluvial units (Af1-Af7), where distal deltaic sandstones and siltstones are identified as (Ad) and eventually reworked marine sandstones (Am) used to deposit in the frontal part of each deltaic lobe (Fig. 4).

The majority of hydrocarbon accumulations so far discovered occur within Silurian and Devonian reservoirs, charged by an organic rich "hot" shale of Tanezzuft Formation at the base of the Silurian.

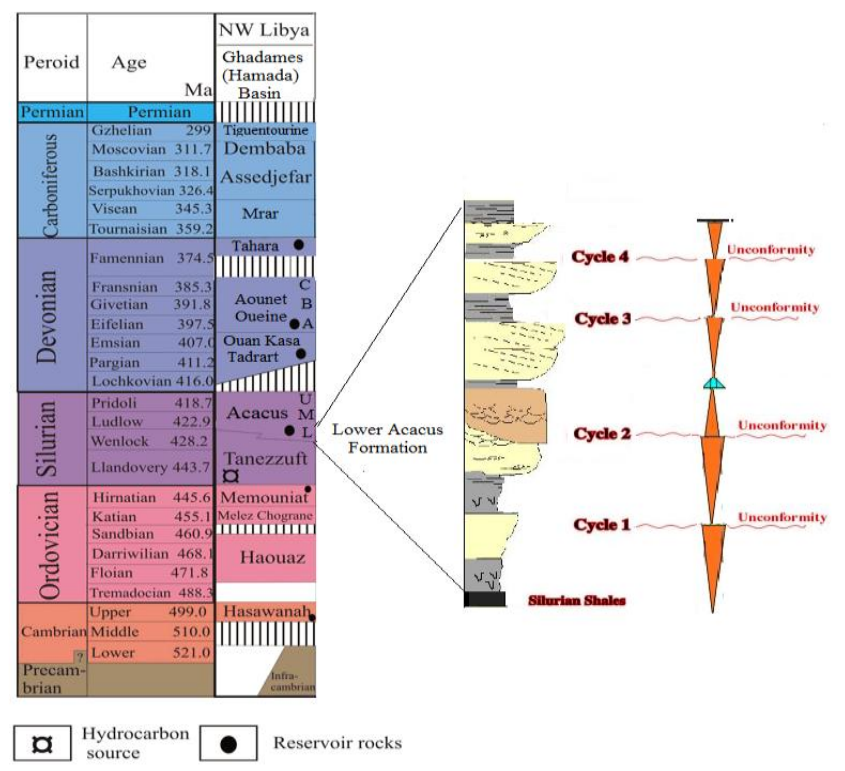

Figure 3. Generalized stratigraphic column of the Paleozoic Formation in the Ghadames (Hamada Basin and the distribution of reservoir and source rocks), NW Libya (modified after [5]). Note the cyclic sequences characterizing the Lower Acacus Formation. 


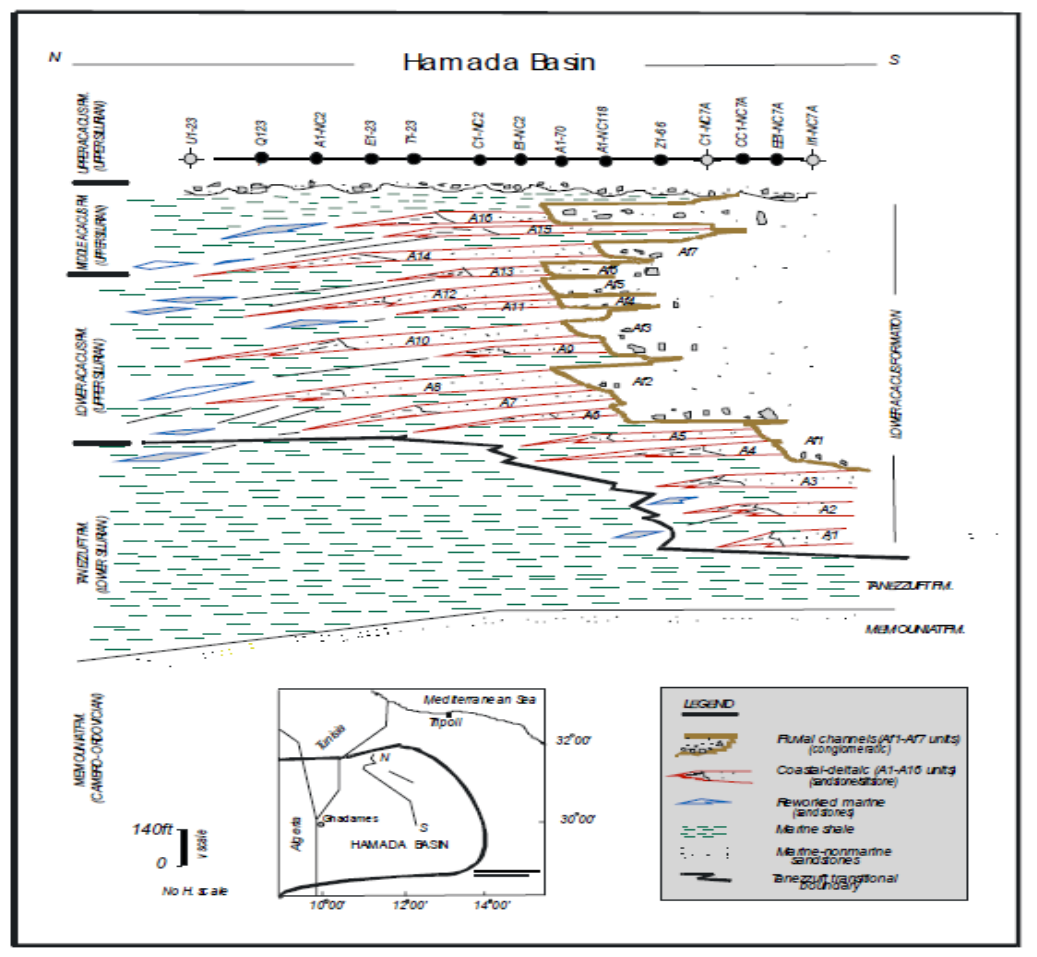

Figure 4. Stratigraphic depositional model for the Lower Acacus Formation, Ghadames (Hamada) Basin, NW Libya (after [4]).

\section{SAMPLing AND MethodS}

A total of $1486 \mathrm{ft}$ of core sections from 16 wells cut in the Lower Acacus Formation at different sandstone units were examined. One hundred thirty nine (139) thin section samples were selected for different purposes. After eliminating oil from the porosity, the samples were impregnated with bluestained resin and then ground deeply enough to avoid artifact porosity. Thin sections were stained by Alizarin red-S for carbonates. Quantification of mineralogy and porosity was performed by counting 300 points per thin section. A standard petrographic microscope Zeiss Axioskop with x10, x20, x40 and $\mathrm{x} 90$ lenses was used.

Stable isotope mass spectrometry analyses were carried out for this study on 30 samples from different facies of the Lower Acacus Formation to determine oxygen and carbon isotopic composition of the authigenic calcite cements associated with these facies. The analyses were conducted by Dr. Fred Longstaffe at the laboratory of the University of Western Ontario, Canada, using MAT 251 mass spectrometer. Oxygen and carbon isotopic compositions were calculated using an orthophosphoric acid $\left(\mathrm{H}_{3} \mathrm{PO}_{4}\right)$-carbon dioxide $\left(\mathrm{CO}_{2}\right)$ fractionation factor of 1.01025 at $25^{\circ} \mathrm{C}$ for calcite. The oxygen and carbon isotope data are reported in $\delta$ notation relative to SMOW for oxygen and PDB for carbon and their values were obtained in \%o.

\section{Sandstone Petrography}

Thin sections point counting through modal analyses (Table 1) revealed that the Lower Acacus sandstones have a rather uniform composition in terms of quartz, feldspar and rock-fragments, being sublitharenites with a few quartzarenites and litharenites. The average composition is $\mathrm{Q}_{93} \mathrm{~F}_{4} \mathrm{~L}_{3}$ for the fluvial sandstones, $\mathrm{Q}_{89} \mathrm{~F}_{1} \mathrm{~L}_{10}$ for the proximal deltaic sandstones, $\mathrm{Q}_{86} \mathrm{~F}_{\text {tr. }} \mathrm{L}_{12}$ for the distal deltaic sandstones/siltstones and $\mathrm{Q}_{88} \mathrm{~F}_{3} \mathrm{~L}_{8}$ for the reworked marine sandstones (Fig. 5). In general, all the sandstones are from silt to coarse grained $(0.25-0.70 \mathrm{~mm}$ for fluvial sandstones, $0.15-0.37 \mathrm{~mm}$ for proximal deltaic sandstones, $0.04-0.1 \mathrm{~mm}$ for distal deltaic siltstones /sandstones and $0.15-0.20 \mathrm{~mm}$ for reworked marine sandstones) (Table 1), with moderate to good sorting, and round to subrounded grains, including some angular and subangular subordinated grains. The clay matrix is from $1 \%$ in the proximal sandstones to $11 \%$ in the marginal distal deltaic siltstones/sandstones. The most common detrital component in all examined sandstones is quartz, dominantly monocrystalline in relation to the polycrystalline quartz grains. The detrital quartz are corroded by the carbonate cements. K-feldspar dominates over plagioclase in all depositional facies and they vary between $0-4 \%$. Some of the 
The Stable Isotope Composition of the Calcite Cement in the Fluvio-Deltaic Reservoir Sandstones of the Lower Acacus Formation, Ghadames (Hamada) Basin, NW Libya

feldspar grains show evidence of dissolution and are occasionally replaced by either kaolinite or carbonates. Generally, alkali and plagioclase feldspars commonly decrease from the fluvial sandstones to distal deltaic siltstones although in some samples the feldspar grains appear fresh and unaltered. Rock fragments are igneous (volcanic), metamorphic (stretched -foliated textures), and scarce sedimentary rocks (shale clasts and dolomite grains), they are ranging from $2 \%$ to $8 \%$ (av. 5\%) of the detrital gain population and demonstrate an overall increase in percentages from the southern fluvial facies northward towards the deltaic facies. Micas (muscovite), zircons, glauconite and chamosite are only minor constituents in the sandstones (av. 2\%). Predominant carbonate cements are total (poikilotopic) calcite cement (av. 8\%) and patchy calcite/dolomite cements (av. 6\%). Both cements (total and patchy types) are common in proximal deltaic sandstones. Besides the carbonate cements, there are other fairly abundant cements such as quartz overgrowths (av. 7\%) found mainly in the fluvial sandstones and pore-filling and replacive kaolinite (av. 9.5\%) and grain coating illitic clay (tr.-5\%) associated with the distal deltaic siltstone/sandstones. Other iron-oxide rimming quartz grains range from $0 \%$ to $7 \%$ (av. 3.5\%) found to be associated with fluvial sandstones (Fig. 6).

Table1. Thin sections point counting averages of framework composition, authigenic cement types and thin section porosity for the various sandstone facies of Lower Acacus Formation, Ghadames (Hamada) Basin, NW Libya.

\begin{tabular}{|c|c|c|c|c|c|c|c|c|c|c|c|c|c|c|c|}
\hline \multirow{2}{*}{ Fades } & \multicolumn{5}{|c|}{ Framework Composition (\%) ${ }^{\mathrm{a}}$} & \multicolumn{3}{|c|}{$\begin{array}{l}\text { Average } \\
\text { Composition }\end{array}$} & \multirow{2}{*}{$\begin{array}{c}\text { Range of } \\
\text { grain size } \\
\text { (mm) }\end{array}$} & \multicolumn{5}{|c|}{ Autiigenic Cement Types (\%) } & \multirow{2}{*}{$\begin{array}{l}\text { TS. }{ }^{c}{ }^{c} \\
(\%)\end{array}$} \\
\hline & Q. & F. & L. & Micas \& Octers & $M x$. & Q & $:$ & ᄂ & & Sil/O & 1 & c & D & cly & \\
\hline $\begin{array}{l}\text { Fluvial } \\
(\mathrm{n}=24)\end{array}$ & 91 & 4 & 2 & 1 & 2 & 93 & 4 & 3 & $0.25 \cdot 0.70$ & 12 & 7 & 6 & - & 2 & 16 \\
\hline 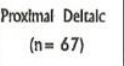 & 88 & 1 & 8 & 2 & 1 & 89 & & 0 & $0.15 \cdot 0.37$ & 4 & . & 14 & 5 & 3 & 12 \\
\hline $\begin{array}{c}\text { Discal Deftalc } \\
(n=32)\end{array}$ & 77 & ๘. & 8 & 4 & 11 . & 86 & & & $0.04 \cdot 0.1$ & 2 & 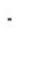 & 9 & 2 & 11 & 4 \\
\hline $\begin{array}{l}\text { Rewarked Martine } \\
(\mathrm{n}=16)\end{array}$ & 84 & 3 & 6 & 2 & 5 & 88 & & 3 & $0.15 \cdot 0.20$ & 4 & . & 11 & 7 & 3 & 10 \\
\hline
\end{tabular}

\footnotetext{
${ }^{\mathrm{a}} \mathrm{Q}=\mathrm{Quartz}, \mathrm{F}=$ Feldspar, $\mathrm{L}=$ Lithic Fragments, Micas \&x Others $=$ Micas and other labile grains, $M \mathrm{x}=$ Matrix.

SII/O = Sillca and Quartz overgrowth, I = Iron-oxldes, $C=$ Calcite, $D=$ Dolomite, Cly = Clay. (All authlgenlc cements are In percent of bullk rock).

'T.S. $\varnothing=$ Thin-section porosity

( $n=$ Number of samples, data obtained from 300 poin counts per thin-section)
}

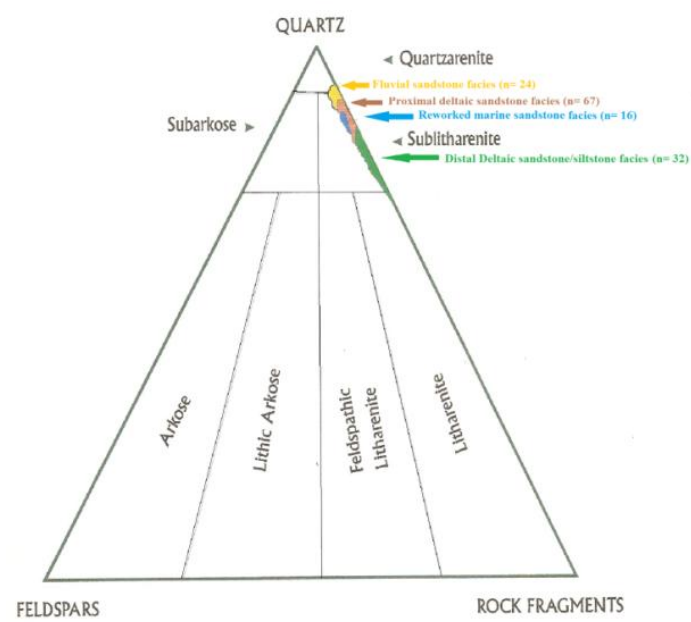

Figure 5. Detrital plot from various facies of the Lower Acacus Formation, Ghadames (Hamada) Basin, NW Libya. ( $n=$ number of samples in each facies, QFR classification of sandstones after [6]) 


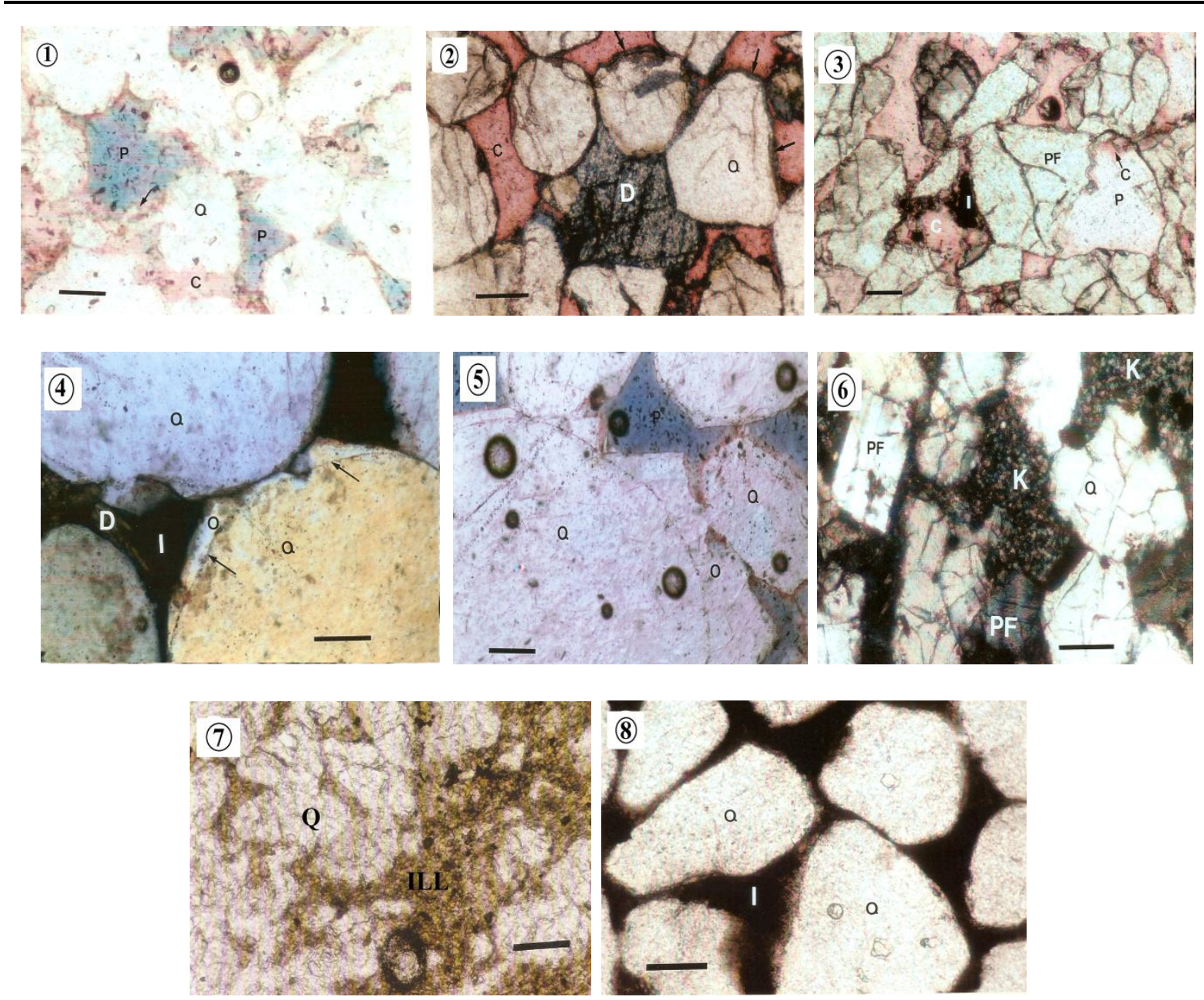

Figure 6. Thin section photomicrographs showing different cement types in the Lower Acacus Formation,

1) Patchy calcite cement "shallow calcite" $(C)$ filling partially pore spaces $(P)$ between quartz grains $(Q)$, in fluvial sandstone unit (Af2), well CC1-NC7A at 9020ft, (PPL). 2) Poikilotopic, pervasive "deep calcite" cement $(C)$ with pink stain and partial ferroan-dolomite cement (D) which show no response to staining and occasionally rimming quartz grains $(Q)$ as indicated by (arrows), in reworked marine sandstone unit (Am), well B3-61 at 8756ft, (PPL). 3) Poikilotopic texture "deep calcite" (C) between quartz grains and the partial dissolved plagioclase feldspar $(P F)$ forming intragranular porosity $(P)$, with some iron-oxide stain $(I)$, in proximal deltaic sandstone unit (A8), well C1-NC2 at 9703ft (PPL). 4) Quartz-overgrowth cement (O) (arrows) interlocked with quartz grains $(Q)$, with partial filling of pores with iron-oxides (I) and some dolomite cement (D), in fluvial sandstone unit (Af3), well Z1-66 at 9131ft (XPL). 5) Quartz overgrowth cement (O) between detrital quartz grains $(Q)$ reduces primary porosity $(P)$ shown on blue, in fluvial sandstone unit (Af2), well CC1-NC7A at $90920 \mathrm{ft}(P P L)$. 6) Kaolinite cement $(K)$ partially filling pores between rigid quartz grains $(Q)$, with some plagioclase feldspar grains (PF), in reworked marine sandstone unit (Am), well Q1-23 at 8461ft, $(X P L) .7)$ Dispersed illite cement (ILL) between very fine quartz grains $(Q)$, in distal deltaic sandstone/siltstone unit (Ad), well Al-NC2 at 7817ft, (PPL). 8) Medium-coarse quartz grains $(Q)$ coated by opaque iron-oxides (I), in fluvial sandstone unit(Af2), well CC1-NC7A at 9017ft, (PPL).( Scale bar in all studied thin sections=0.1 $\mathrm{mm})$

\section{OXYGen-Carbon Isotopic Compositions in CAlCite CEMENT}

On the basis of previous petrographic study, 30 samples from the various facies of the Lower Acacus Formation were chosen for oxygen and carbon isotope study of calcite cement (Table 2). These samples were taken from different sandstones and siltstones units in different facies of different origin; from fluvial (Af2-Af7 units) to proximal deltaic (Al-A14 units) to distal deltaic (Ad units) to reworked marine (Am units) throughout the Ghadames (Hamada) Basin. The analyses show the following relationships:

Calcite is one of the dominant cements in the Lower Acacus Formation, ranging from $6 \%$ to $14 \%$ of the rock (Table 1). Calcite was not always pure; occasionally magnesite, manganoan, and iron-rich ferroan calcites are present in some samples. 
The Stable Isotope Composition of the Calcite Cement in the Fluvio-Deltaic Reservoir Sandstones of the Lower Acacus Formation, Ghadames (Hamada) Basin, NW Libya

Table2. Oxygen and carbon-isotope compositions of calcite cement, in sandstone units of Lower Acacus Formation, Ghadames Basin, NW Libya.

\begin{tabular}{|c|c|c|c|c|c|c|c|}
\hline \multirow{2}{*}{$\begin{array}{l}\text { Lower Acacus } \\
\text { Unics }\end{array}$} & \multirow{2}{*}{ well } & \multirow{2}{*}{ Depch (Ie) } & \multirow{2}{*}{ Rock trpe } & \multirow{2}{*}{$\begin{array}{c}\text { Calcite cement } \\
\text { yppe }\end{array}$} & \multicolumn{2}{|c|}{$8180(\%)$} & \multirow{2}{*}{$\begin{array}{c}813 C(\% 0) \\
\text { (PDB) }\end{array}$} \\
\hline & & & & & (SMOW) & (PDB) & \\
\hline$A B 3$ & EEI-NC7A & 8810 & Figst. & Shallow & 20.4 & -10.1 & -10.1 \\
\hline$A \sqrt{3}$ & $"$ & 8812 & vfesce-sisc. & " & 20.8 & -9.8 & -11.5 \\
\hline An & CCI-NC7A & 7840 & vfgssc-sisc. & $"$ & 16.4 & -14.2 & -12.9 \\
\hline Af2 & " & 9020 & mgst. & $"$ & 20.3 & -10.2 & -12.9 \\
\hline Af2 & B3-61 & 9345 & fgsc. & $"$ & 20.5 & -10.1 & -9.7 \\
\hline Af4 & Z1-66 & 9081 & fiest. & $"$ & 18.7 & -11.7 & -12.0 \\
\hline$A B 3$ & " & 9130 & fgsc. & " & 20.1 & -10.4 & +7.6 \\
\hline Ar3 & Al-NC118 & 10040 & frgst. & " & 17.7 & -12.7 & -10.7 \\
\hline$A / 3$ & ZI-NC100 & 11680 & fesc. & " & 20.9 & -9.7 & -9.6 \\
\hline Ar7 & $C 1-61$ & 7110 & mgst. & " & 20.9 & -9.7 & -8.1 \\
\hline Afs & $"$ & 7525 & messt. & " & 25.5 & -5.1 & -5.3 \\
\hline Af2 & $"$ & 8199 & vfrgst. & " & 16.1 & -14.3 & -12.9 \\
\hline \multirow{2}{*}{$A 8$} & $\mathrm{C}_{1-\mathrm{NC2}}$ & 9703 & mgst. & Deep & 19.7 & -10.8 & -13.1 \\
\hline & $"$ & 9725 & mgst. & " & 19.3 & -11.2 & -12.4 \\
\hline \multirow{2}{*}{ A10 } & D $1-61$ & $\mathbf{8 8 4 5}$ & mgst. & $"$ & 15.6 & -14.8 & -15.1 \\
\hline & $"$ & 8866 & mesc. , & " & 14.1 & -16.2 & -20.4 \\
\hline \multirow[t]{5}{*}{ A 12} & B1-NC2 & 8542 & mesc & " & 24.5 & -6.1 & -17.2 \\
\hline & $"$ & 8555 & mest. & " & 21.71 & -8.9 & -18.0 \\
\hline & C1-70 & 7913 & fgsc. & $"$ & 18.3 & -12.2 & -9.5 \\
\hline & B3-61 & 8893 & mgst. & $"$ & 18.4 & -12.2 & -19.9 \\
\hline & $"$ & 8969 & $"$ & $"$ & 23.9 & -6.7 & -19.2 \\
\hline \multirow[t]{4}{*}{ A 14} & $T 1-23$ & 8454 & frest. & $"$ & 15.4 & -14.9 & -20.7 \\
\hline & $"$ & 8473 & vfgst. & $"$ & 19.8 & -10.6 & -18.4 \\
\hline & $\mathrm{CI}-\mathrm{NC2}$ & 8855 & figst. & " & 20.6 & -10.0 & -12.4 \\
\hline & E1-NC2 & 9105 & mgsc. & " & 19.3 & -11.2 & -12.9 \\
\hline \multirow[t]{2}{*}{ Ad } & A1-NC2 & 7814 & slst. & $"$ & 15.6 & -14.8 & -3.8 \\
\hline & $"$ & 7817 & sisc. & $"$ & 15.3 & -15.2 & -11.1 \\
\hline \multirow[t]{4}{*}{ Am } & Q1-23 & 7461 & Fiss. & $"$ & 15.1 & -15.3 & -15.8 \\
\hline & $"$ & 7471 & fest. & " & 14.9 & -15.5 & -16.0 \\
\hline & $"$ & 8180 & fesst. & " & 14.8 & -15.6 & -16.4 \\
\hline & " & 8485 & vfgst. & $"$ & 17.5 & -13.0 & -18.5 \\
\hline
\end{tabular}

Af2-Af7 = Lower Acacus fluvlal sandstone units, A8-A I $4=$ Lower Acacus proximal delta front sandstone units, $\mathrm{Ad}=$ Lower Acacus distal delta fron sllstone units, $\mathrm{Am}=$ Lower $\mathrm{Acacus}$ reworked marthe sandstone units.

*slst. = siltstone, vfgst. $=$ very fine-grained sandstone, figs. = fine-grained sandstone, $\mathrm{mgst} .=$ medium-grained sandstone.

Note: All measurements are in the units of the studied wells.

Two types of calcite cement have been distinguished based on texture and manner of occurrence in thin-sections:

1) Patchy calcite cement, is a cement with a patchy texture of irregular scattered forms, low in iron, usually manganoan-calcite, partially filling primary porosity between quartz grains. Patchy calcite cement occurs in the southerly shallower portions of the basin characterized the fluvial, iron oxiderich sandstones (Fig. 7A).

2) Poikilotopic calcite cement, it has poikilotopic texture $(0.5-15 \mathrm{~mm}$ in diameter) with continuous and hornogeneous distribution (Fig. 7B). This calcite is associated with magnesium and ferroan carbonate, and found to be filling mainly secondary porosity and occasionally replacing feldspars. Poikilotopic, pervasive calcite cement occurs in the northerly deeper parts of the basin characterized the deltaic sandstones (A8-A14 units).

The transition between these cement-type regions is broad and gradational. Well densities are inadequate at this point to make specific statements regarding the details of the transitions. For the purposes of the regional discussion the patchy calcite cement will be termed as Shallow calcite cement and the poikilotopic cement will be termed as the Deep calcite cement. 

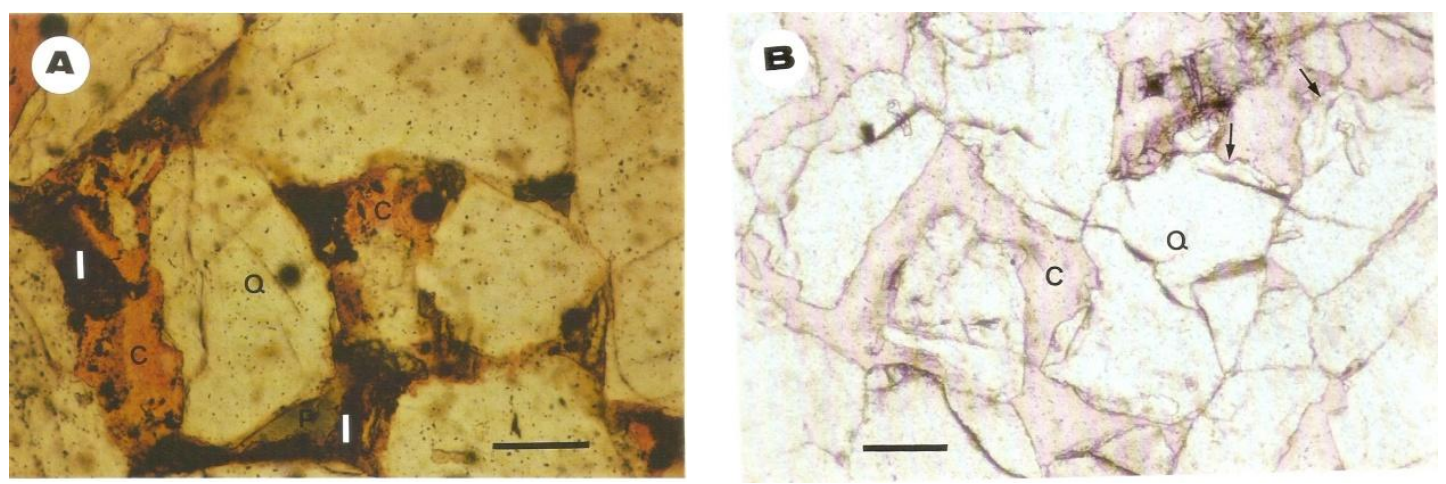

Figure 7. A) Thin section photomicrograph in the medium to coarse grained fluvial sandstone (Af3) of Lower Acacus Formation in well EE1-NC7A at 8810ft, showing patchy "shallow" calcite cement (C) filling partially pore spaces $(P)$ between quartz grains $(Q)$. Matrix between quartz grains contains some opaque iron oxides (I) filling partially pore spaces" Scale bar $=0.1 \mathrm{~mm}^{\prime \prime}$. B) Thin section photomicrograph in the fine to medium grained proximal deltaic sandstone (A12) of Lower Acacus Formation in well B1-NC2 at 8555ft, showing poikilotopic, pervasive "deep" calcite cement (C), with floating detrital quartz grains $(Q)$ of corroded boundaries (arrows), "Scale bar $=0.1 \mathrm{~mm}$ ".

A plot of oxygen isotope $\left(\delta^{18} \mathrm{O} \%\right.$ ) versus carbon isotope composition $\left(\delta^{13} \mathrm{C} \%\right.$ ) of calcite cement (Fig. 8) illustrates the variations encountered in the different units of the Lower Acacus Formation. For the fluvial sandstone units (Af2-Af7), shallow calcite has $\delta^{18} \mathrm{O}$ and $\delta^{13} \mathrm{C}$ values ranging from +16.1 to $+22.6 \%$ SMOW, and -12.9 to $+7.6 \%$ PDB, respectively. On the other hand the deep calcite cement associated with proximal deltaic sandstone units (A8-A14) are characterized by relatively lower $\delta^{18} \mathrm{O}$ values ( +14.1 to $+19.8 \%$ SMOW), and have highly negative $\delta^{13} \mathrm{C}$ values $(-20.7$ to $-9.5 \% \mathrm{PDB})$.

Cement in the reworked marine sandstone units $(\mathrm{Am})\left(\delta^{18} \mathrm{O}=+14.8\right.$ to $+17.5 \%$ SMOW, and $\delta^{13} \mathrm{C}=-$ 18.5 to $-15.6 \%$ PDB) is of the deep calcite variety and is similar to the majority of deep calcite cements of deltaic origin (Fig. 8).

Distal deltaic units (Ad) have poikilotopic cement textures and record isotopic compositions $\left(\delta^{18} \mathrm{O}=\right.$ +15.3 to $+15.6 \%$ SMOW, and $\delta^{13} \mathrm{C}=-11.1$ to $-3.5 \%$ PDB) similar to the majority of deep calcite cements of deltaic origin (Fig. 8), with some highly negative $\delta^{13} \mathrm{C}$ values (-11.1 to $-3.5 \%$ PDB).

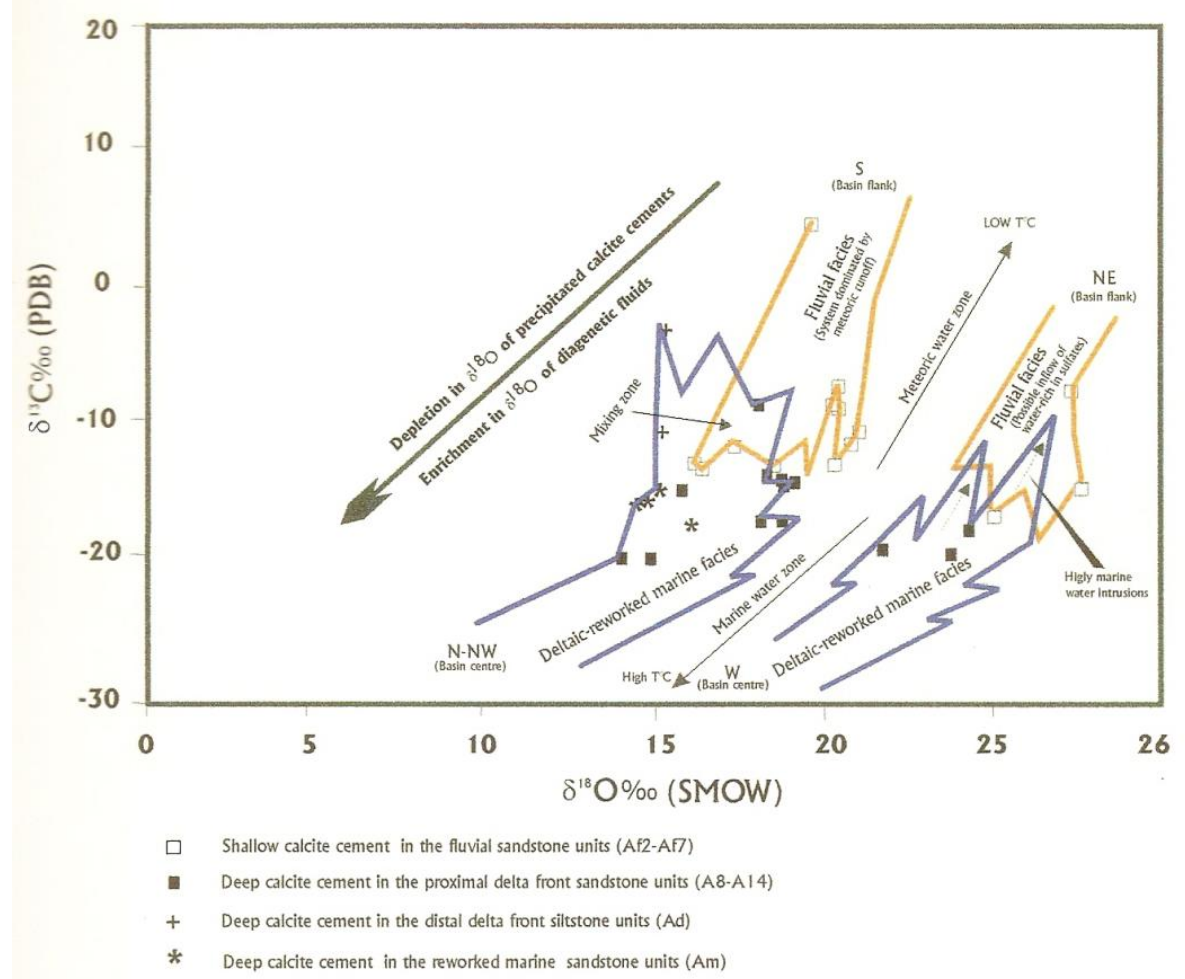

Figure 8. Oxygen versus carbon isotope compositions of calcite cements in the various sandstone/siltstone units In the two possible deltaic systems (NE-W and $S-N N W)$ of the Lower Acacus Formation, Ghadames (Hamada) Basin, NW Libya. 


\section{INTERPRETATION OF ISOTOPIC COMPOSITION OF CALCITE CEMENTS}

In fluvial sandstone units (Af2-Af7) the $\delta^{18} \mathrm{O}$ values are consistent with precipitation of the shallow calcite cement from meteoric water at low temperature (e.g. [7]; [8]). The lighter negative $\delta^{13} \mathrm{C}$ nature of this calcite suggests an involvement of organically derived $\mathrm{CO}_{2}$. The probable source of such $\mathrm{CO}_{2}$ is the oxidation of organic matter from the overlying soil during shallow diagenesis; local meteoric recharge to these fluvial sandstones occurs by percolation through the associated soil zone (overbank deposits) (e.g. [9]).

According to Bottinga (1968) [10] and Friedman and $\mathrm{O}^{\prime} \mathrm{Nei1}(1977)$ [11] the $\mathrm{CO}_{2}$-calcite fractionation for carbon at low temperatures (soil temperatures from $+5^{\circ} \mathrm{C}$ to $+20^{\circ} \mathrm{C}$ ) is about $-13 \%$ to $-11 \%$ PDB. Such fractionation would equate to calcite carbon isotopic $\left(\delta^{13} \mathrm{C}\right)$ values in the range $(-12.9$ to $-5.3 \%$ o PDB; Table2) recorded for the fluvial sandstones (Af2-Af7) or facies. The single high positive $\delta^{13} \mathrm{C}$ value recorded (+7.6\% $\mathrm{PDB}$ ) (Table 2, Fig. 8) would be consistent with conditions in fluvial sandstone units with associated carbonaceous materials altered by shallow microbial degradation (e.g. [12]; [13]; [14]). The relative similarities of the oxygen isotope compositions for the shallow calcite cement throughout the fluvial sandstone units suggests that the water in these sandstones were fairly uniform in composition and would be consistent with a fresh water origin.

The lower $\delta^{18} \mathrm{O}$ values of the deep calcite cement associated with the deltaic sandstone units (A8-A14) or facies are compatible with these cements being crystallized from formation waters having a composition similar to sea water (e.g. [7]). Such values may also have resulted from increasing temperature and water-rock interaction as burial diagenes is progressed (e.g. [14]). The negative $\delta^{13} \mathrm{C}$ values probably record the increasing importance with depth of bicarbonate production by thermal decarboxylation (e.g.[8]; [15]).

It is important to note that it is difficult to determine the timing (early or late) of the patchy shallow to homogeneously distributed deep calcite cements. However the data suggest that two possible deltaic systems prograded from NE to W and from S to NNW may be inferred (Fig. 8), in which both the shallow and the deep calcite cements were formed synchronously. The shallow cement was precipitated in the fluvial sandstones from meteoric waters and the deep calcite cement was precipitated in the deltaic sandstones as the waters flowed down-basin becoming progressively more saline and reducing (Fig. 8).

\section{Conclusions}

The reservoir sandstones from the Upper Silurian Lower Acacus Formation in the Ghadames (Hamada) Basin were deposited in fluvial, deltaic "transitional" and marine environments. The average composition is $\mathrm{Q}_{93} \mathrm{~F}_{4} \mathrm{~L}_{3}$ for the fluvial sandstones, $\mathrm{Q}_{89} \mathrm{~F}_{1} \mathrm{~L}_{10}$ for the proximal deltaic sandstones, $\mathrm{Q}_{86} \mathrm{~F}_{\text {tr. }} \mathrm{L}_{12}$ for the distal deltaic sandstones/siltstones and $\mathrm{Q}_{88} \mathrm{~F}_{3} \mathrm{~L}_{8}$ for the reworked marine sandstones. In general, all the sandstones are from silt to coarse grained. The principal cements occluding porosity include carbonates, quartz overgrowth, and some subordinated kaolinite and illite. Two types of calcite cements have been distinguished based on texture and manner of occurrence in thin-sections: 1) Patchy calcite cement which regarded as shallow calcite cement, occurs in the southerly shallower portions of the basin characterized the fluvial, iron oxide-rich sandstones (Af2Af7 units). 2) Poikilotopic calcite cement which regarded as deep calcite cement, occurs in the northerly deeper parts of the basin characterized the deltaic sandstones (A8-A14 units).

Isotopic compositions of calcite cements in the Lower Acacus Formation reflect different regional paleo-fluid regimes (eg. meteoric to mixed water). Relatively shallow depth patchy calcite-cement is associated with sandstone units "or facies" of fluvial origin. These cements formed from enriched $\delta^{18} \mathrm{O}$ meteoric waters at low temperature with lighter negative $\delta^{13} \mathrm{C}$ values. Deeper depth poikilotopic calcite-cement formed from waters depleted in $\delta^{18} \mathrm{O}$ with negative $\delta^{13} \mathrm{C}$ values that became progressively hotter, more reducing and saline as they flowed down-dip to mix with the saline waters in sandstone- siltstone units "or facies" of deltaic origin.

The impact of the calcite cements in the study of sandstone reservoirs of Lower Acacus Formation may has positive influence when shallow depth patchy cement preserving the original primary porosity. However, the deeper depth poikilotopic cement have minor impact in these reservoir, and only secondary porosity occurs when organic acids from interbedded shales circulated at depth. 


\section{ACKNOWLEDGEMENT}

I would like to express my sincere thanks and appreciation to the Department of Earth Sciences, Faculty of Science at University of Benghazi for their encouragement to publish this paper. I am also thankful to Arabian Gulf Oil Company (AGOCO), Benghazi-Libya, for providing the data-base for this study. I am also wish to thank Mr. Moukhtar Ibrahim, AGOCO Laboratory, Benghazi-Libya, for assisting me on preparing all petrographic thin sections used in this study. Special gratitude is expressed to Dr. F. Longstaffe, University of Western Ontario-Canada, for conducting the oxygencarbon analyses for this study and his precious suggestions. I am particularly thankful to Dr. M. Wadleigh and Dr. M. Wilson, Earth Sciences Department at Memorial University of NewfoundlandCanada, for their fruitful discussions of many issues related to oxygen-carbon isotope analyses and interpretation. Deep thanks are also extended to anonymous reviewers for their constructive comments and thoughtful discussions on this paper. Special thanks and gratitude go to my family for their patience and support to finish this paper.

\section{REFERENCES}

[1] Elfigih, O.B. (2000), Regional diagenesis and its relation to facies change in the Upper Silurian, Lower Acacus Formation, Hamada (Ghadames) Basin, northwestern Libya, Ph.D. thesis Memorial University of Newfoundland, St.John's, Newfoundland, Canada, 399p.

[2] Acheche, M. Hedi, Rabet, A.M., Ghariani, H., Ouahchi, A., and Montgomery, S.L. (2001), Ghadames Basin, Southern Tunisia: A Reappraisal of Triassic Reservoirs and Future Prospectivity, AAPG Bull., 85 (5): 765-780.

[3] Hassan S. Hassan, Kendall Christopher C. G. (2014), Hydrocarbon Provinces of Libya: A Petroleum System Study, AAPG Memoir 106: Petroleum Systems of the Tethyan Region, P. 101-141.

[4] Elfigih, O. B. (1991), The sedimentology and reservoir characteristics of the Lower Acacus Formation, NC2 concession, Hamada Basin, NW Libya, MSc.thesis, Memorial University of Newfoundland, St.John's, Newfoundland, Canada, 569p.

[5] Craig, J., Rizzi, C., Said, F., Thusu, B., Luning, S., Asbali, A., Keeley, M.L., Bell, J. F., Durham, M. J., Eales, M. H., Beswetherick, S., and Hamblett, C. (2006), Structural Styles and Prospectivity in the Precambrian and Palaeozoic Hydrocarbon Systems of North Africa.

[6] Folk, R. L. (1980), Petrology of sedimentary rocks: Austin, Texas, Hemphill, 182p.

[7] Ayalon, A., and Longstaffe, F. J. (1995), Stable isotope evidence for the origin of diagenetic carbonate minerals from the Lower Jurassic Inmar Formation, southern Israel: The Journal of the international Association of Sedimentologist, Vol. 42, No.1, p. 147.

[8] Tang, Z., Parnell J., and Longstaffe F. J. (1997), Diagenesis and reservoir potential of PermianTriassic fluvial/lacustrine sandstones in the southern Junggar Basin, northwestern China, AAPG, Vol. 81, No. 11, p. 1843-1865.

[9] Schwartz, F. W., and K. Muehlenbachs (1979), Isotope and ion geochemistry of groundwater in the Milk River aquifer, Alberta: Water Resources Research, Vol. 15, p. 259-268.

[10] Bottinga, Y. (1968), Calculation of fractionation factors for carbon and oxygen exchange in the system calcite-carbon dioxide-water: Journal of Physical Chemistry, Vol. 72, p.800-808.

[11] Friedman, I, and O'Neil, J. R. (1977), Compilation of stable isotope fractionation factors of geochemical interest, In M. Fleischer (ed.), Data of geochemistry, sixth edition: U. S. Geological Survey Professional paper 440-KK, 12p.

[12] Curtis, C. D., Coleman, M. L, and Love, L. G. (1986), Pore water evolution during sediment burial from isotopic and mineral chemistry of calcite, dolomite and siderite concretions. Geochim. Gosmochim. Acta., 50, p.2321-2334.

[13] Longstaffe, F. J., Racki, M. A. and Ayalon, A. (1992), Stable isotope studies of diagenesis in berthierine-bearing oil sands, Clearwater Formation, northeastern Alberta, In Kharaka, Y. K., and Maest, A. S. (eds.), Proceedings of the $7^{\text {th }}$ international Symposium on Water-Rock Interaction, Park City, Utah: A.A. Balkerma Publications, p. 955-958. 
[14] Longstaffe, F. J. (1994), Stable isotopic constraints on sandstone diagenesis in the Western Canada sedimentary basin, In Parker, A., and Sellwood, B.W. (eds.), Quantitative diagenesis: recent developments and applications to reservoir geology: Dordrecht, Kluwer Academic publishers, p.223-274.

[15] Lu, J., Wilkinson, M., Haszeldine, R. S., Boyce, A. J. (2011), Carbonate cements in Miller field of the UK North Sea: a natural analog for mineral trapping in $\mathrm{CO}_{2}$ geological storage, Environmental Earth Sciences, Springer, Vol. 62, No.3 (2011), p.507-517.

\section{AUTHORS' BIOGRAPHY}

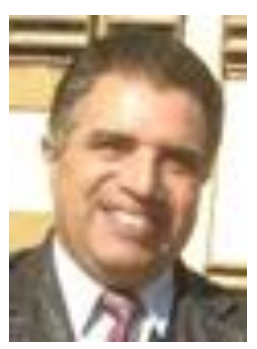

Dr. Omar B. Elfigih, is an associated professor and petroleum geologist at the Department of Earth Sciences, University of Benghazi. Born on Dec. 16.1959, he has an MSc and $\mathrm{PhD}$ in petroleum geology from Memorial University of Newfoundland-Canada. Worked for the Arabian Gulf Oil Company (AGOCO) as petroleum geologist, technical advisor and led the Ghadames Basin group for hydrocarbon exploration researches. He worked as private consultant and exploration geologist with BP-Libya. He was the head of the Department of Earth Sciences-University of Benghazi from Oct. 2014 to Oct. 2016. Head of scientific affairs at the University of Technical Research for Engineering Sciences (UTRES), Benghazi-Libya. Research interests involve sedimentary basin analysis for hydrocarbons exploration, reservoir characterization and evaluation and studies in petroleum system and stratigraphic models in exploration. He is a member in many geological societies; the Geological Association of Canada (GAC), the Earth Sciences Society of Libya (ESSL) and the American Association of Petroleum Geologists (AAPG). 